\title{
ISSUES OF TRADE INTEGRATION BETWEEN EU, CIS AND RUSSIA: INFLUENCES OF MULTILATERAL TRADE IN AGRICULTURAL COMMODITIES
}

\author{
Vasily Erokhin $^{1}$, Anna Ivolga ${ }^{2}$, Marina Lescheva ${ }^{3}$ \\ (1) associate professor \\ Department of Management and Marketing, Moscow University of Finance and Law \\ (2) associate professor \\ Department of Tourism and Service, Stavropol State Agrarian University \\ (3) professor \\ Department of Business Analysis and Audit, Stavropol State Agrarian University \\ E-mail: basilic@list.ru, annya iv@mail.ru,marina_lesheva60@mail.ru
}

\begin{abstract}
Trade with agricultural products in last decades becomes more and more internationalized and globalized. A global trading system is now both freer and fairer than ever before and this will boost global prosperity and can make a significant contribution to the global economic development. Favorable conditions for development of international trade with agricultural products are caused by the trade liberalization, development of trade unions and free trade areas all over the world. The paper includes the overview of the WTO threats and opportunities for the Russian agriculture and trade with agricultural products in CIS and EU. This is also related to state support of agricultural production in Russia and CIS and its influence on volumes, directions, structure and effectiveness of bilateral CIS-EU trade with agricultural products.
\end{abstract}

Keywords: trade, agricultural commodities, integration, export JEL classification: F13, F15

\section{Introduction}

WTO is currently the leading organization regulating the issues of international trade. In 2012 the process of Russia-WTO negotiations had been completed, but many questions related to the accession remain critical. The majority of Russian agricultural industries cannot equally compete with foreign producers. The dependence on import deliveries is critically high. Local agricultural and food products cannot find their customer neither on foreign nor even on local Russian markets. At another point, trade integration can bring not only damages, but also advantages. Along with a wide range of disadvantages given by the WTO system to the Russian agriculture, many experts reasonably observe series of opportunities, especially in the sphere of agricultural export. Russia is a traditional exporter of agricultural products to CIS and EU, and WTO membership can provide easier access to foreign markets fro Russian agricultural producers. Trade integration is also a process actively developed nowadays among Russia, Belarus and Kazakhstan (agreement on custom union) and among Russia and Ukraine - the second biggest CIS agricultural producer. These processes supported by the Russia's membership in WTO will influence significantly the character of international trade with agricultural products in the region. 


\section{Material and methods}

The current state of EU-CIS-Russia trade is analyzed on the example of main goods having the biggest ratio in the structure of bilateral trade turnover. Special attention is paid to agricultural products, since agriculture is one of the most "sensitive" spheres influenced by trade integration, including trade agreements within CIS and membership of some of CIS countries in WTO. The period of analysis was 2001-2011. The analysis involved main exporting and importing countries for all analyzed goods. Methods of quantitative and comparative analysis were implemented. The data summarized for 4 CIS countries were compared to EU-27 data. Trade data for this research are from Final Report "International trade and international cargo flows in 2011" by VLANT consulting company. An alternative source is the "Commodity trade between EU-27 and CIS countries, 2000-2010" by Eurostat.

\section{Results and discussion}

World trade in agricultural products in 2010 increased 12\% compared to 2008 and reached record highs. Increased trade in agriculture was due increased product demand from major emerging economies compared to previous years. World agricultural trade reached an all-time high, at least 12\% (expressed in Euros) above the previous record set in 2008. The impact of the economic crisis led to a contraction of $6 \%$ in global agricultural exports in 2009 but they rebounded by $20 \%$ in 2010 . World main exporters of agricultural products in 2011 are EU-27, USA and Brazil. These 3 countries increased their export volumes in 2011 in comparison with 2008. China took the 4th place in 2011, while exports from Canada and Argentina grew in much lower rates, comparing to exports from China. China, having the world's biggest population, is able to provide sufficient internal requirements of agricultural products and food and, moreover, to increase export volumes. (Erokhin - Ivolga, 2012)

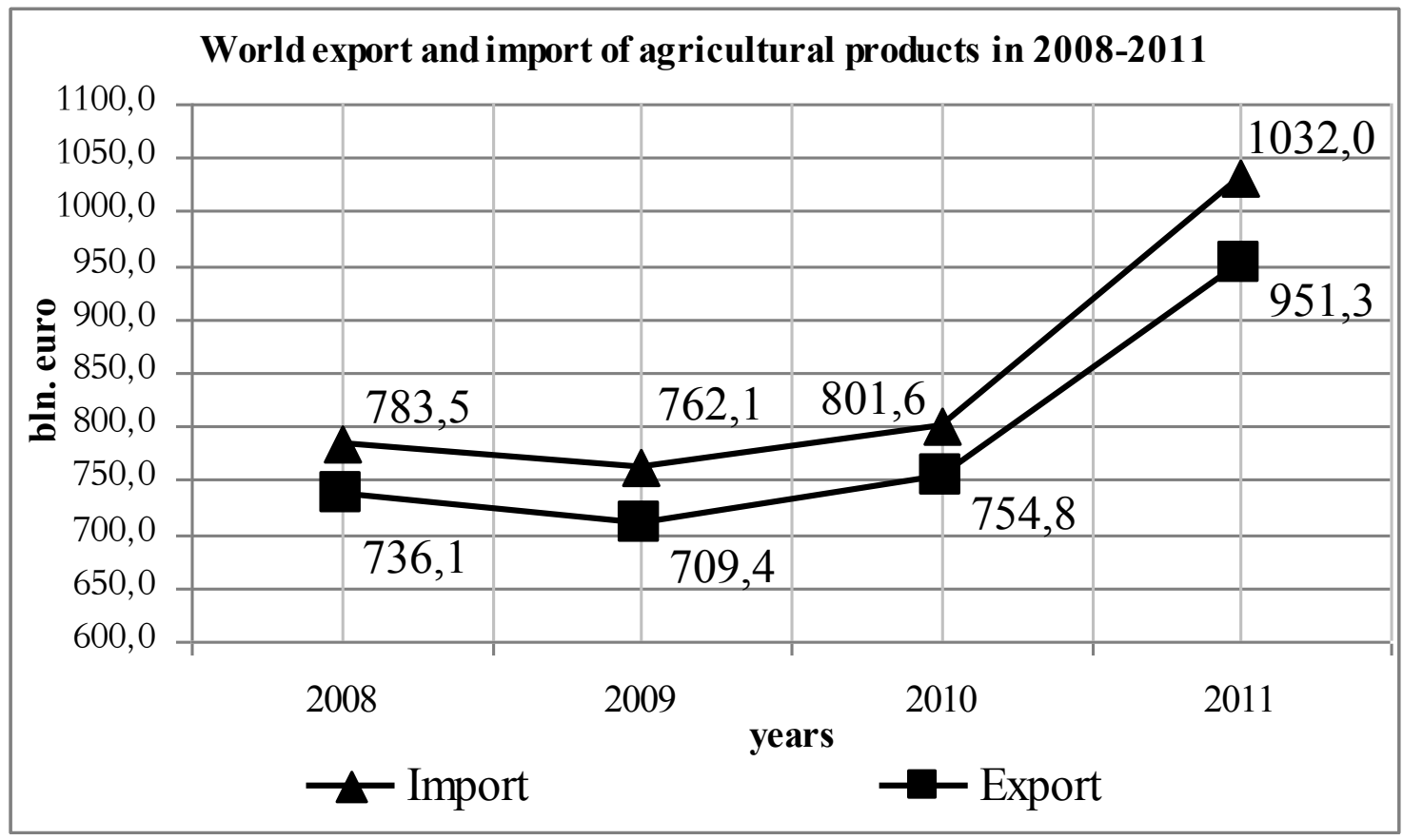

Figure 1: World export and import of agricultural products in 2008-2011, bln. $€$ Source: own editing, 2013.

The indicative trend of the post-crisis international economic development is the advanced growth of interregional trade, observed in 2006-2011, even despite the economic recession. 
This shows the strengthening differentiation of labor at the macroeconomic level. The highest increase of exports was observed for the regions specialized in raw goods supplies. The best import dynamics were in the developing countries (as a result of global imports appreciation) and again the same "raw" regions - as a result of growth of their revenues on the global market, and enlargement of their effective demand.

The EU as well as the other top exporters all benefited from buoyant markets. Following the slump in 2009 , the EU, the US and Brazil bounced back with over $20 \%$ growth in exports, to reach record levels in 2010-2011. The EU's trade balance improved to the extent that it emerged from recession as a net exporter in 2011, for the first time since 2006. The $€ 6$ billion agricultural trade surplus is largely due to expansion in the value of exports, driven by stronger demand for final products, as the EU's key trading partners come out of recession and higher prices for commodities and intermediate goods.

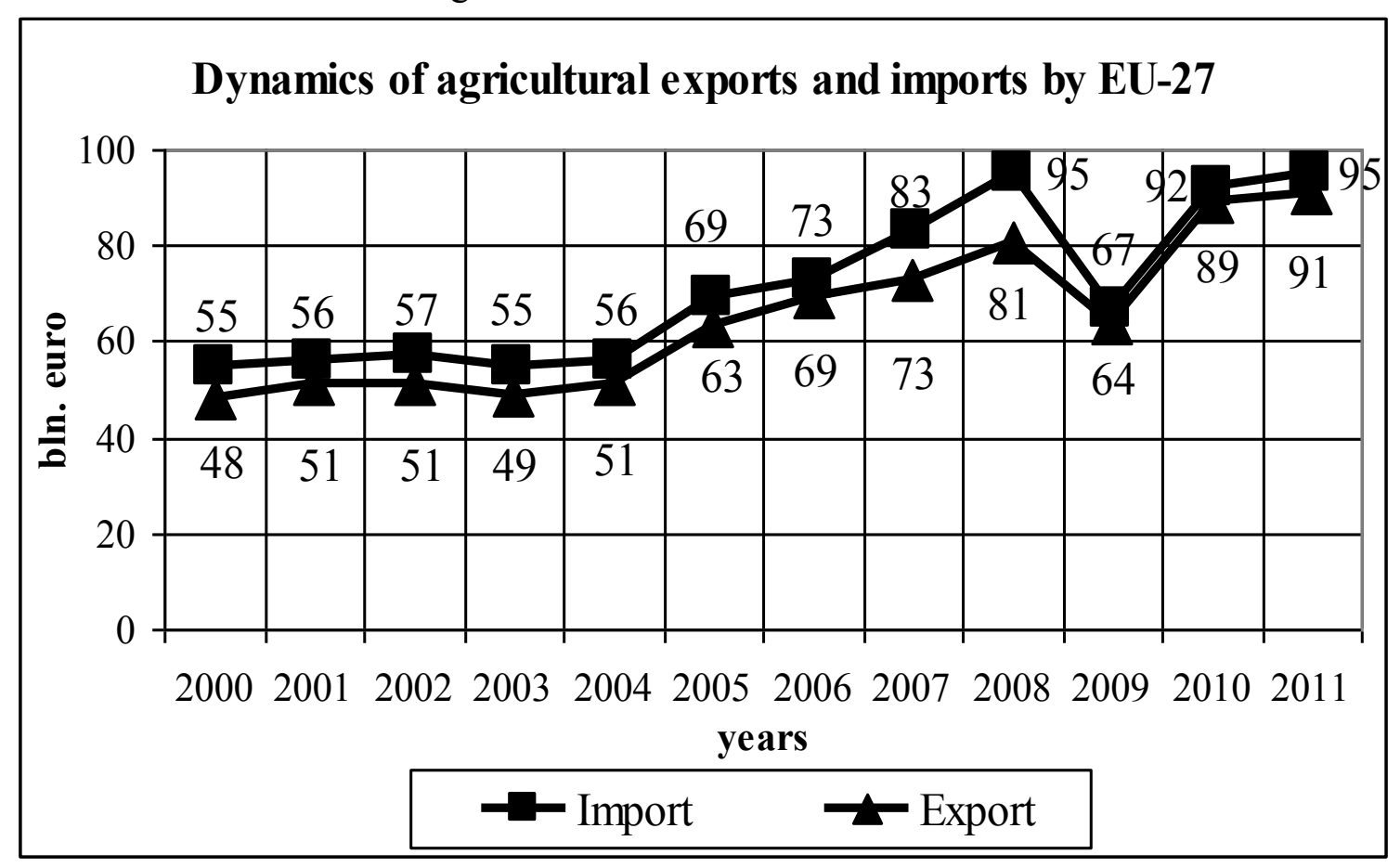

Figure 2: Dynamics of agricultural exports and imports by EU-27, bln. $€$ Source: own editing, 2013.

The EU remains by far the world's biggest importer with imports worth $€ 83$ billion in 20082011, well ahead of the US. EU imports grew by $9 \%$ in 2011 though they remain 5\% below the peak of 2008 , when they reached $€ 88$ billion. This is a result of the sharp drop of over $12 \%$ in 2009 after two years of very strong growth of over 13\% per year. The EU's share of global imports was over $19 \%$ in 2009 . US imports grew strongly by $17 \%$ in 2011 , having suffered a less severe decline (just 5\%) than the EU in 2009.

The EU's trade balance continued to improve in 2011 to the extent that it switched from being a net importer with a trade deficit of $€ 2.5$ billion in 2009 to a net exporter, for the first time since 2006, with an agricultural trade surplus of over $€ 6$ billion. The surplus is largely due to growth in the value of exports after the contraction of trade in 2009 linked to economic crisis and the drop in commodity prices. The EU and the other top exporters all benefited from buoyant export sales. The EU's export profile has changed little in recent years. Final products and other products together account for $69 \%$ of the value of EU exports in 2008-2011, while intermediate products and commodities represent $20 \%$ and $9 \%$ respectively. 


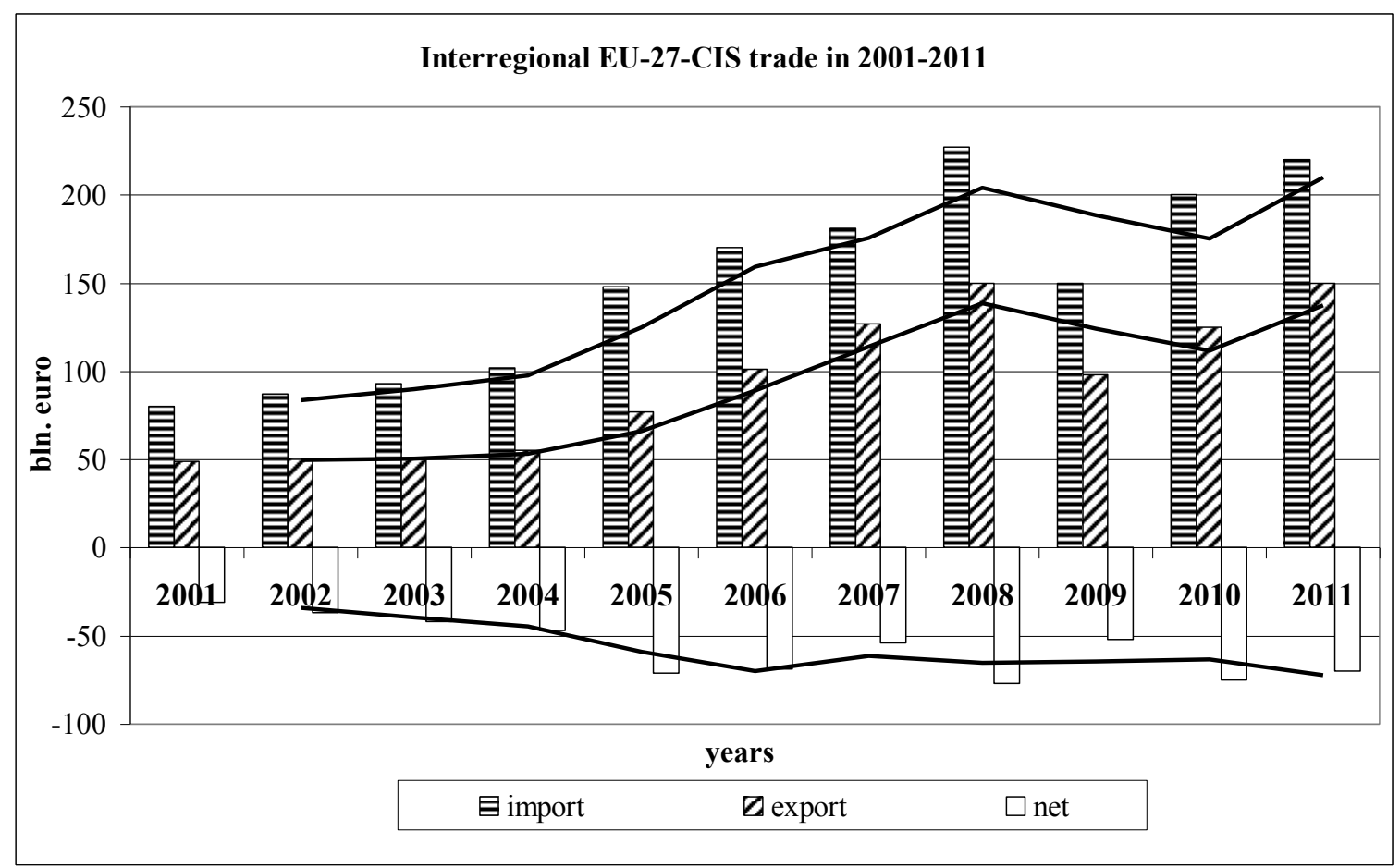

Figure 3: Interregional EU-27-CIS trade in 2001-2011 (in bln. €)

Source: own editing, 2013.

EU-CIS trade flow remained one of the world's biggest from 2009-2011, although South-East Asia - East Asia trade flow, the most dynamic one in last decade, was progressively reaching similar levels. CIS is the relevant EU-27 trade partner. The annual volume of interregional trade almost tripled - from $€ 109.7$ bln. in 2000 to $€ 330.0$ bln. in 2011 . However, a significant drop of exports and imports in 2009 was recorded as a result of global economic recession. Following rapid (up to $30 \%$ annually) growth of interregional trade volumes in 2009-2011, let us forecast the recovery of export and import volumes at 2008 levels even in 2012, as well as the achievement of a horizon of $€ 250 \mathrm{bln}$. imports and $€ 170 \mathrm{bln}$. exports in 2013 (Erokhin - Ivolga, 2011).

In 2001-2011 (except «crisis» 2008-2009), the annual increase of EU-27 imports from CIS countries was $10.1 \%$. Such a high level can be explained primarily by the growth of imports volume from Russia as well as imports increase from Kazakhstan, Azerbaijan and Ukraine. Russia's share in the structure of foreign trade turnover between EU-27 and CIS countries remains significant, including the period of global economic recession and considering the nonmembership WTO status of Russia until 2012. Russia's share is 79\% of EU-27 imports from CIS countries and $71 \%$ of EU-27 exports to CIS countries. The structure of Russian exports to the EU is homogenous during the last decades - over 78\% of Russian exports to EU-27 is mineral fuel (2011). EU-27 exports to Russia are much more diversified, mainly consisting of machineries, equipments and transport vehicles (44\% in 2011) (Erokhin - Ivolga, 2011). 


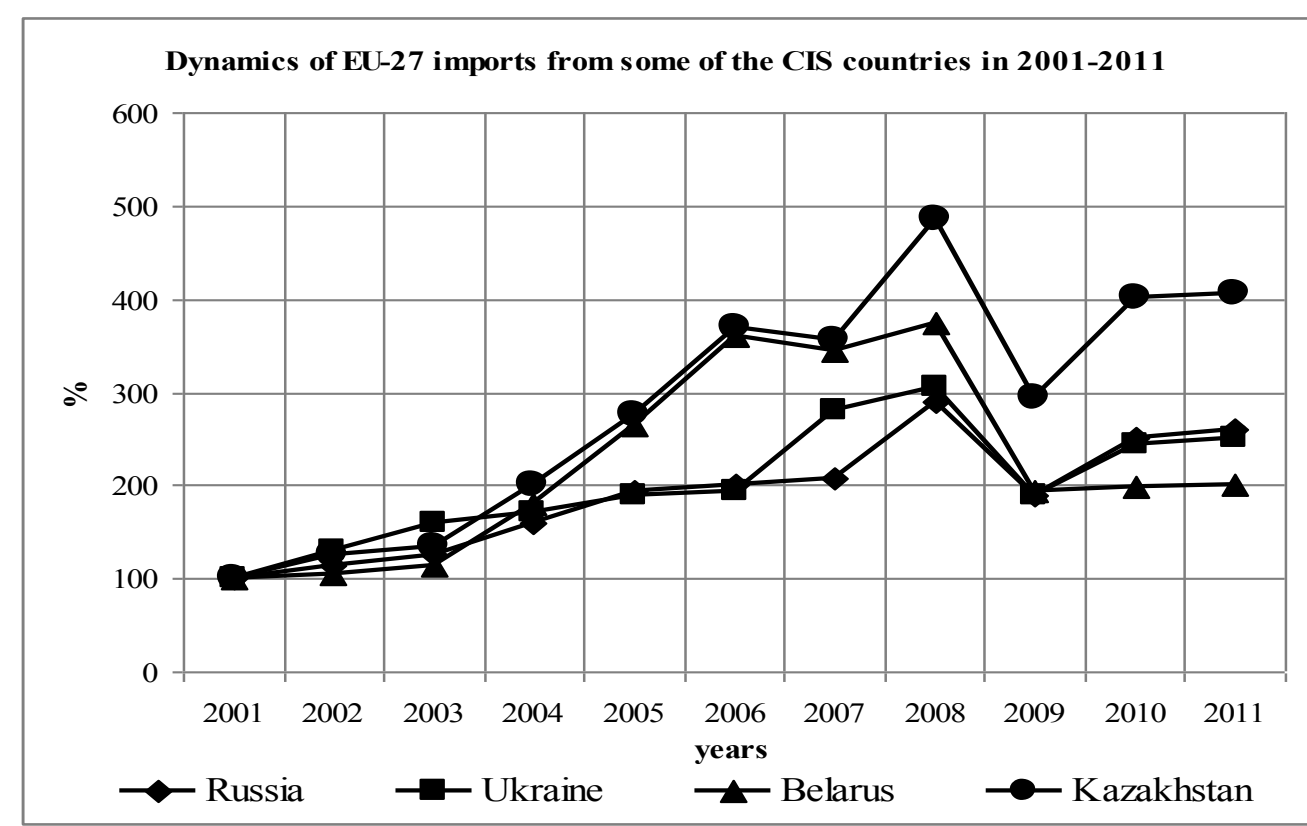

Figure 4: Dynamics of EU-27 imports from some of the CIS countries in 2001-2011 (in \%) Source: own editing, 2013.

During the same period of 2001-2011, the annual average increase of EU-27 exports to CIS countries was $13.9 \%$. The given increase was provided primarily by the growth of exports to Russia, Ukraine, Belarus and Kazakhstan. Incomplete recovery of European demand for CIS raw goods (especially fuel), caused by the financial and economic difficulties and growth of international competition on the European market, until now prevents the recovery of "EU-27CIS" trade flow volumes up to the pre-crisis levels. The highest growth rates can be observed for grain and coal sectors. The significant increase is noticed for non-metallic mineral raw materials and other fuels. However, despite the general increasing trend, some of the commodity groups demonstrated negative dynamics: pipeline gas, oil and iron ore. CIS countries after USSR collapse developed multi-directionally, but in general they were primarily oriented to European Union as the largest market for their products. Many partnership trade agreements between CIS and EU countries were concluded during 2001-2011 (Nilson, 2011).

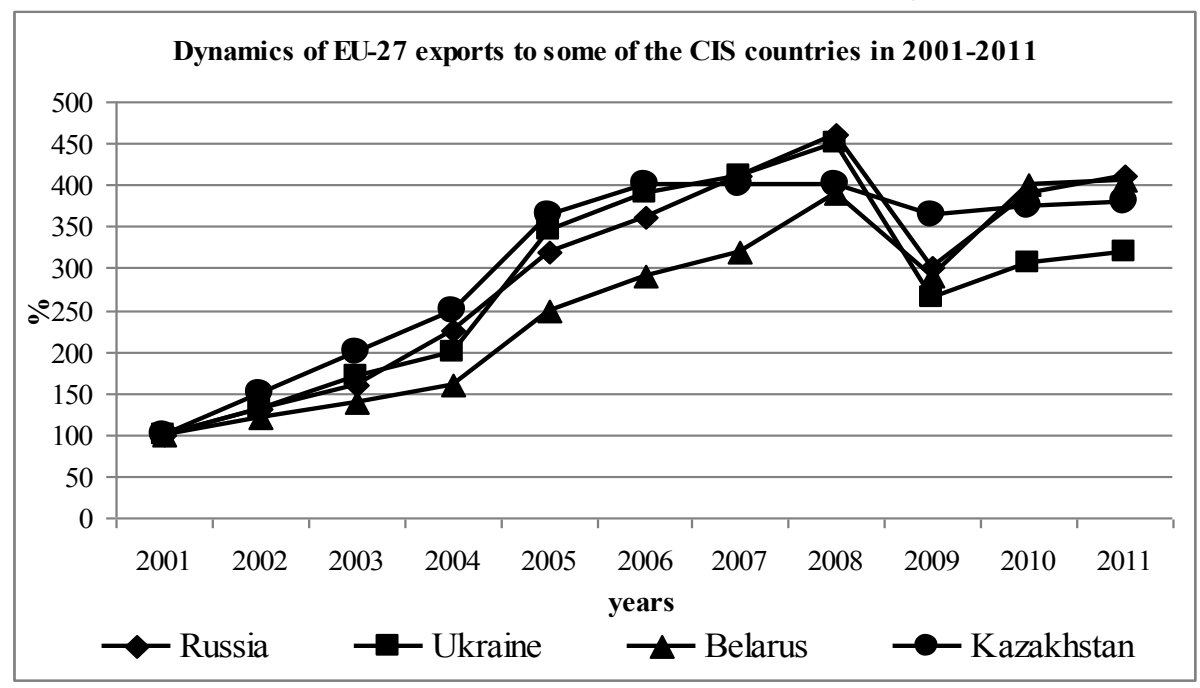

Figure 5: Dynamics of EU-27 exports to some of the CIS countries in 2001-2011 (in \%) Source: own editing, 2013.

At the moment, the EU Commission actively supports its partners in trade development, for example, through partnership and collaboration agreements (Liapis, 2011). Most of the Central 
Asian countries within CIS are the beneficiaries of the Global System of Preferences (trade) of EU-27 countries, as well as active participants of integration in the frameworks of WTO. Membership of some of CIS countries in WTO and recent Russian accession to this global trade system can change the structure and main tendencies of EU-CIS trade significantly. This is especially related to EU-CIS trade with agricultural products, since agriculture is supposed to be one of the most "sensitive" spheres influenced by trade agreements within CIS and Russian accession to WTO.

As we have already outlined, trade integration could bring both advantages and treats. In order to assess the probable influenced of Russia's accession to WTO we have to analyze the principal obligations undertaken by the country and see how their introduction may affect the domestic agricultural production and Russia's foreign trade with agricultural commodities. Member obligations in agriculture are different from the standard ones, usually undertaken by other accessing countries. According to the standard approach each accessing country "binds" the aggregate volume of support that distorts trade on the level of a three year period preceding the accession. This volume is a subject of reduction during a short period after accession. The allowed level of support for Russia is $\$ 9 \mathrm{bln}$, which is twice as much as the level permitted according to the standard rules. The allowed level will be decreased gradually, and after 2018 it will be "bound" on the existing level. Russia confirmed that after WTO accession (as well as of today) the export agricultural subsidies would not be implemented. According to the Research Institute of Agricultural Economics of the Russian Academy of Agricultural Sciences, the average weighted rate for agricultural and food commodities in Russia will be lessened by a third (from $15.6 \%$ to $11.3 \%$ by the end of the transition period).

Membership in WTO will obviously limit the opportunities in independent regulation of the external economic activity. Particularly, bound import tariffs will limit the maneuverability and flexibility of state custom and tariff regulations. The economic conditions of agricultural production will get worsened because of the low competitiveness of Russian production caused by the lack of the production factors of high quality, as well as by the weak interaction between agriculture and the rest of industries. It will become harder and more difficult for the state to protect domestic farmers, and the access of the foreign food commodities on the Russia's domestic market will become easier because of the lower import custom tariffs. This may lead to the decrease in the national production. However, the "secret" of foreign farmers' success on the Russian market is not in the high quality of their products only. Agriculture is one of the most protected and "closed" industries. The main method of protection is to provide a huge volume of subsidies to domestic producers. Annual agricultural expenses of WTO member states exceeds dozens of millions US dollars. Most of this money they spend on the measures that distort trade and production. Obviously, this affects the global agricultural market negatively, leads to overproduction and landslide of prices.

Global demand for agricultural and food commodities is under-elastic. Food and agricultural products are essential commodities; that is why developed countries aim at assurance of their food security by means of domestic production (except, perhaps, Japan) and saturate domestic markets with high-quality own-produced food commodities. To entry those markets foreign producers have to have some substantial competitive advantage. This is usually not the case of developing countries, which do not have sufficient resources to support their farmers and deliver such competitive advantages to their products.

Consumers in developed countries already have all necessary food commodities of required quality; there is no reason to expect any essential growth of market capacity. Moreover, there 
are high custom barriers (either tariffs or sanitary regulations) on the way of foreign agricultural commodities (Josling et al., 2010).

Principles of competition and fair self-regulation of global agricultural market, which underlie WTO activities, seem too hard for developing countries, particularly in the conditions of high state support of domestic agricultural complexes by developed countries, distorting fair competition (Liapis, 2011). However, for Russia the situation is not so unpromising. Alongside with such serious apprehensions there are quite realistic effects of agricultural trade liberalization. De jure Russia was granted with a light regime of access to foreign markets when accessing WTO and participating in trade and economic integration. But one can benefit here not so much by an expansion to the developed countries' markets as by getting more predictable operation regime on traditional markets, i.e. expansion of trade between CIS and other traditional Russia's trade partners.

\section{Conclusions}

It is possible to forecast that in the mid-term, the structure of EU-27-CIS foreign trade turnover will not get changed significantly. CIS-EU trade flow will primarily consist of raw commodities. Its largest constituent will remain oil. There will be also relevant (but not comparable to oil in their sizes) shares of pipeline gas, coal, petrochemicals and iron ore. CIS deliveries would be mainly formed by Russia. Ukraine and Kazakhstan would also become big suppliers. The main CIS importer among EU-27 countries will be Germany, followed by Italy. The Netherlands and Poland will increase their shares in EU-27 imports from CIS countries.

Export of agricultural products from EU-27 to CIS countries will grow in the mid-term. The growth will be caused by a number of reasons, particularly:

1. Continuing liberalization of inter-regional trade within CIS, as well as a result of multilateral EU-CIS agreements.

2. Russia, which is the largest economy of the region, accessed to WTO.

3. Low competitiveness of CIS domestic agricultural producers comparing to EU and US farmers, supported by their governments (especially in food production and high-level food processing where added value is the largest).

4. Incomparably lower volumes of state support for domestic agricultural producers not only in CIS-countries, but even in Russia, that does not provide sufficient protection of inter-regional market and do not allow to develop effectively high-quality food processing and food production in CIS-countries (Josling et al., 2010).

WTO and trade liberalization obviously bring a set of opportunities for an accessing country. WTO is based on an equality of rights and obligations. This means that EU countries are obliged to open their domestic markets for CIS agricultural and food products. However, most of the CIS-countries, including Russia, cannot fully benefit from these opening opportunities. The state is not able to support the massive expansion of domestic farmers to European markets. Transition period can take long time. If CIS and Russia do not use new opportunities today, better times may not come at all. 


\section{References}

1. Erokhin V. - Ivolga A. (2011): Entrepreneurship in Agriculture: New Challenges of International Trade Integration. Contemporary Agriculture: the Serbian Journal of Agricultural Sciences. Vol. 60. No. 3-4. 398-402. p., ISSN 0350-1205.

2. Erokhin V. - Ivolga A. (2012): International Trade with Agricultural Products: Influence of Market Globalization and Integration. In: Horska E. (ed.): Food Sciences and Business Studies. Nitra, Slovak University of Agriculture in Nitra, 410 p., 61-83. p., ISBN 978-80-552-0815-2.

3. International trade and international cargo flows in 2011 (final report), Consulting company VLANT (2012). Available at: http://vlant-consult.ru/ (accessed November 2013)

4. Josling T. et al. (2010): Understanding International Trade in Agricultural Products. One Hundred Years of Contributions by Agricultural Economists. Am. J. Agr. Econ. Vol. 92 (2). 424-446. p., ISSN 0002-9092. http://dx.doi.org/10.1093/ajae/aaq011

5. Liapis P. (2011): Changing Patterns of Trade in Processed Agricultural Products. OECD Food, Agriculture and Fisheries Papers. No. 47, 122 p. http://dx.doi.org/10.1787/5kgc3mq19s6d-en

6. Nilson A. (2011): Commodity Trade between EU-27 and CIS Countries, 2000-2010. Eurostat. Statistics in focus. Vol. 40. Available at: http://epp.eurostat.ec.europa.eu/ (accessed November 2013) 